\title{
PENGARUH DIET LIPIDA LEMAK KEDELAI TERHADAP INSIDEN HIPERTENSI
}

\author{
Tiwi Yuniastuti \\ Prodi Kesehatan Lingkungan STIKES Widyagama Husada \\ t_yuniastuti@yahoo.com
}

\begin{abstract}
Hypertension is known as one of the causes of death in Indonesia. Patients with hypertension are at high risk of not only heart disease, but also of other diseases, such as kidney disease, nerve, and blood vessels. The purpose of this research was to know the effect of soy milk consumption on the incidence rate of hypertension. The retrospective cohort design was used by having the accidental sampling. This study used a completely randomized design with two variables and two groups of samples: the group without hypertension and hypertensive groups. The sampling technique was conducted by giving the questionnaire, open interviews and secondary data. The Fisher's Exact Test was used to analyze the data. The results showed that there was significant influence between the consumption of soy milk and the hypertension incidence in the group of 40 years old people. Based on the findings, by consuming soy milk, the hypertension and other cardiovascular diseases can be decreased because of the vasodilator effect on the flavonoids contained in the soy milk.
\end{abstract}

Keywords: Hypertension, Soy Milk, Vasodilators 


\begin{abstract}
Abstrak
Hipertensi dikenal sebagai salah satu penyebab kematian di Indonesia. Penderita hipertensi tidak hanya beresiko tinggi menderita penyakit jantung, tetapi juga menderita penyakit lain, seperti penyakit ginjal, syaraf, dan pembuluh darah. Tujuan dalam penelitian ini adalah untuk mengetahui pengaruh konsumsi susu kedelai terhadap tingkat insiden hipertensi. Penelitian ini dilakukan dengan rancangan cohort retrospective dengan pengambilan sampel secara accidental sampling. Penelitian ini menggunakan rancangan acak lengkap dengan 2 variabel dan 2 kelompok sampel, yaitu kelompok tanpa hipertensi dan kelompok hipertensi. Teknik pengambilan sampel dilakukan dengan kuisioner, wawancara terbuka, dan data sekunder. Data dianalisa dengan metode Exact Fisher Test. Hasil penelitian menunjukkan adanya pengaruh yang signifikan antara konsumsi susu kedelai dengan insiden hipertensi pada kelompok umur diatas 40 tahun. Hal ini berkaitan dengan adanya efek vasodilator pada flavonoid yang terkandung di dalam susu kedelai. Kesimpulan dari penelitian ini adalah adanya pengaruh konsumsi susu kedelai dengan insiden hipertensi. Untuk itu, peningkatan konsumsi susu kedelai kemungkinan dapat menurunkan insiden hipertensi dan penyakit kardiovaskuler lainnya secara jangka panjang.

Kata kunci: Hipertensi, Susu Kedelai, Vasodilator
\end{abstract}

\section{PENDAHULUAN}

Hipertensi didefinisikan sebagai peningkatan tekanan darah sistolik sedikitnya $140 \mathrm{mmHg}$ atau tekanan diastolic sedikitnya $90 \mathrm{mmHg}$. Perjalanan penyakit hipertensi sangat perlahan. Penderita hipertensi kemungkinan tidak merasakan atau menunjukkan gejala yang spesifik selama bertahun - tahun. Faktor predisposisi dari hipertensi adalah gaya hidup, obesitas, konsumsi alkohol, asupan natrium tinggi dan kebiasaan merokok. Faktor resiko yang berperan sebagai factor tambahan lingkungan biologis yang berkaitan dengan penyakit jantung adalah stress dan psikososial.

Aterosklerosis sebagai penyakit multifaktorial dan bukti yang ada menunjukkan bahwa factor predisposisi hipertensi juga dapat mempercepat aterogenesis (Price dan Wilson, 2005). Faktor resiko dari penyakit atherosklerosis juga merupakan predisposisi dari disfungsi endotel. Dan disfungsi endotel merupakan tahap inisiasi dari proses terbentuknya atherosklerosis (Cai dan Harrison, 2000).

Intervensi untuk mengatasi disfungsi endotel ini lebih dikembangkan berdasarkan manifestasi klinis dari disfungsi endotel. Intervensi ini terdiri dari diet rendah kolesterol, berhenti merokok dan olahraga. Sedangkan intervensi farmakologis melalui pemberian minyak ikan, pemakaian suplemen antioksidan dan L-arginine, penggunaan obat penurun lipid, ACE inhibitor, calcium-channel blocker, dan terapi sulih hormon. Terapi sulih hormon atau yang dikenal sebagai hormone replacement therapy merupakan terapi yang dikembangkan sebagai pencegahan primer dan sekunder dari penyakit kardiovaskuler. Penggunaan estrogen eksogen sebagai terapi sulih estrogen masih menimbulkan perdebatan karena efek sampingnya (Rachman, et al., 2004). 
Estrogen berperan sebagai antioksidan karena kesamaan strukturnya dengan vitamin E. Produksi radikal bebas endogen normal mempunyai dua peran yang berlawanan, yaitu dapat memberikan efek yang menguntungkan dan merugikan. Dalam kondisi fisiologis, terjadi keseimbangan antara jumlah produksi radikal bebas dan status antioksidan. Tetapi jika keseimbangan ini hilang, dan terjadi produksi radikal bebas yang berlebihan, maka dapat menimbulkan kondisi patologis. Salah satunya adalah terjadi peningkatan lipid peroksidasi dan keusakan inetgritas membran; kerusakan pada protein dan DNA mitokondria dan inti sel. Sistem antioksidan mencegah dan menghentikan reaksi radikal bebas (Persky, et al., 2000). Stres oksidatif muncul ketika terjadi over produksi ROS. Efek antioksidan yang diberikan oleh estrogen melalui mekanisme peningkatan aktivitas catalase, SOD, glutathione peroxidase dan glutathione reductase (Liu, et al., 2006).

Fitoestrogen adalah bahan kandungan dari tanaman yang memiliki sifat seperti estrogen. Fitoestrogen biasanya memiliki struktur non steroid dan dapat meniru atau bersifat antagonis terhadap kerja estrogen endogen, dimana fitoestrogen dapat secara kompetitif berikatan dengan estrogen reseptor dalam organ reproduksi dengan memiliki afinitas yang lebih rendah (Tamaya, 2005). Efek protektif vaskuler dari fitoestrogen kemungkinan dimediasi via penghambatan langsung dari proliferasi sel otot polos vaskuler melalui reseptor estrogen pada sel otot polos vaskuler. Dehydrodaidzein yang merupakan fitoestrogen dengan aktivitas agonis yang kuat terhadap estrogen reseptor. Beberapa studi menunjukkan bahwa estrogen menghambat proliferasi sel otot polos vaskuler dan mencegah respon neointimal terhadap jejas. Estrogen reseptor berada di sel endotel dan sel otot polos vaskuler (Shen, et al., 2006; Mendelsohn dan Karas, 1999).

Pada penelitian dengan menggunakan aorta hewan coba hipoestrogen yang dipapar genistein murni menunjukkan bahwa penurunan jumlah hormone estrogen yang beredar di dalam darah menyebabkan adanya perubahan fungsi dan jumlah endothel intak dalam pembuluh darah. Perubahan ini dapat memperbesar insiden kardiovaskuler pada wanita menopause. Genistein yang diberikan pada kondisi hipoestrogen dapat mempertahankan sel endotel yang intak dan fungsi vasodilatasi dari aorta (Yuniastuti, 2008).

Isoflavone memiliki kesamaan struktur dengan estrogen mamalia. Kelompok besar isoflavone yang secara alamiah berasal dari tumbuhan disebut sebagai fitoestrogen. Isoflavone banyak ditemukan pada tanaman leguminase, terutama pada kacang kedelai dan hampir semua makanan olahan kedelai akan memberikan sumber diet non nutrisi bioaktif ini. Meskipun proporsi tertinggi suatu makanan mengandung kedelai tetapi produk olahan kedelai ini bisa tanpa isoflavone. Hal ini terjadi karena isoflavone bermigrasi ketika terjadi fraksinasi protein kedelai pada saat pengolahan (Setchell dan Cassidy, 1999). Sebagian besar masyarakat mengambil manfaat dari fitoestrogen melalui pola konsumsi makanan 
sehari-hari dengan mengkonsumsi makanan sumber fitoestrogen, seperti makanan berbahan dasar kedelai.

Konsumsi yang umum dari diet berbasis kedelai adalah susu kedelai (soya milk) yang merupakan lipida lemak kedelai.Untuk itu perlu dilakukan penelitian tentang pengaruh lipida lemak kedelai terhadap perbaikan disfungsi endotel yang termanifestasi secara klinis sebagai hipertensi. Dan hasil penelitian ini diharapkan dapat memberikan gambaran yang lebih jelas tentang manfaat kedelai sebagai intervensi alternative penyakit kardiovaskuler.

\section{METODE PENELITIAN}

Penelitian ini menggunakan desain cohort retrospective. Pengambilan data dilakukan dengan metode survey dan pengambilan sample secara purposive. Variabel yang digunakan adalah variabel konsumsi susu kedelai dan variabel insiden hipertensi. Data dianalisa dengan metode Exact Fisher dengan SPSS.16.

\section{HASIL PENELITIAN}

Reponden secara rutin mengkonsumsi susu kedelai setiap hari, hasil yang diperoleh adalah berkurangnya serangan jantung dan kestabilan tekanan darah selama mengkonsumsi susu kedelai. Responden yang tidak mengkonsumsi susu kedelai sama sekali mengalami hipertensi dan rasa nyeri pada persendian. Responden yang mengkonsumsi susu kedelai dan disertai dengan makanan berbasis kedelai yang lain, pada umumnya hanya merasakan penyakit flu dan batuk. Timbulnya demensia pada lansia yang mengkonsumsi makanan berbasis kedelai saja tanpa disertai konsumsi protein hewani dan susu kedelai ada pada beberapa responden, tetapi korelasi dan pengaruhnya tidak diketahui secara pasti.

Data hasil penelitian menunjukkan adanya insiden hipertensi pada responden yang diteliti. Data penderita hipertensi ditunjukkan dalam tabel 1.

Tabel 1 Data responden Penderita Hipertensi

\begin{tabular}{ll}
\hline Responden & Jumlah \\
\hline Penderita hipertensi & 30 \\
Bukan penderita hipertensi & 14 \\
Total & 44 \\
\hline
\end{tabular}

Data konsumsi susu kedelai, menunjukkan bahwa 28 responden mengkonsumsi susu kedelai secara rutin, dan 16 responden tidak mengkonsumsi susu kedelai secara rutin. Data konsumsi susu kedelai ditunjukkan pada tabel 2.

Tabel 2 Data Konsumsi Susu Kedelai Responden

\begin{tabular}{ll}
\hline Responden & Jumlah \\
\hline Tidak mengkonsumsi susu kedelai & 28 \\
Mengkonsumsi susu kedelai & 16 \\
Total & 44 \\
\hline Hasil penelitian tentang & insiden
\end{tabular}
hipertensi dibandingkan dengan konsumsi susu kedelai, menunjukkan bahwa responden yang mengkonsumsi susu kedelai secara rutin (16 responden) tidak menderita hipertensi. Tetapi pada responden yang tidak mengkonsumsi susu kedelai secara rutin, menunjukkan bahwa 14 responden tidak menderita hipertensi dan 14 responden menderita hipertensi. Hal ini ditunjukkan pada tabel 3. 
Tabel 3 Data Penderita Hipertensi dan Responden yang Mengkonsumsi Susu Kedelai

\begin{tabular}{lll}
\hline Responden & $\begin{array}{l}\text { Tidak mderita } \\
\text { hipertensi }\end{array}$ & Menderita hipertensi \\
\hline Tidak mengkonsumsi susu kedelai & 14 orang & 14 orang \\
Mengkonsumsi susu kedelai & 16 orang & 0 orang \\
Jumlah total & 30 orang & 14 orang \\
\hline
\end{tabular}

Hasil penghitungan statistik menunjukkan bahwa ada pengaruh yang signifikan antara konsumsi susu kedelai dengan insiden hipertensi. Nilai yang diperoleh adalah $\mathrm{p}=0.000$ dengan $\alpha=0.05$.

\section{PEMBAHASAN}

Hasil penelitian menunjukkan bahwa ada pengaruh signifikan antara konsumsi susu kedelai dengan insiden hipertensi. Hal ini terjadi kemungkinan adanya pengaruh kardioprotektif yang diberikan oleh kandungan gizi susu kedelai. Kedelai mengandung isoflavon yang merupakan bentuk umum dari fitoestrogen. Isoflavon memiliki bentuk yang mirip dengan estrogen sintetik poten. Isoflavon ini terdiri dari genistein dan daidzein.

Berdasarkan Yuniastuti (2008), genistein memiliki kemampuan potensial untuk melindungi endotel intak dari pengaruh radikal bebas yang dihasilkan dari proses degeneratif sel. Selain itu, genistein juga memiliki kemampuan untuk menjaga fungsi endotel dalam keseimbangan sekresi faktor vasodilator. Potensi sebagai faktor protektif kardiovaskuler ini yang kemungkinan berperan dalam mengurangi insiden kardiovaskuler pada individu yang secara rutin mengkonsumsi susu kedelai.

Pada tanaman, isoflavone dalam keadaan inaktif ketika berbentuk sebagai glikosida, tetapi ketika gula residunya dihilangkan, maka senyawa ini akan menjadi aktif. Senyawa tanaman ini difermentasi oleh mikroflora dalam intestine sehingga dapat diabsorbsi. Dalam koloni mikroflora, genistein dimetabolisme menjadi p-ethyl phenol. Daidzein, genistein, equol, dan O-Dma merupakan fitoestrogen utama yang terdeteksi dalam urine dan darah.

Ketersediaan glikosida isoflavone dan mekanisme absorbsi intestinal dari isoflavon pada manusia masih belum jelas. Bukti dari perfusi intestin dan studi dengan kultur in vitro mengindikasikan glikosida isoflavon sangat sedikit diabsorbsi dan ketersediaannya membutuhkan hidrolisis awal dari gula oleh $\beta$ glukosidase intestin untuk diserap ke dalam sirkulasi. Ini kemungkinan karena produk yang mengandung isoflavone dalam kondisi glikosida, dapat sedikit efektif ketika mereka lebih sedikit diabsorbsi atau dengan kata lain kondisi ini memungkinkan fitoestrogen lebih cocok terhadap berbagai mekanisme metabolisme individu.

Bentuk glikosida dari isoflavon memiliki kerja estrogenik yang lebih lemah, dibandingkan dengan bentuk aglikon. Mereka dapat berikatan secara lemah dengan alpha dan beta estrogen reseptor dan ekspresi transkripsi yang dipengaruhi reseptor sangat rendah. Ketika gugus gulanya dihilangkan, 
isoflavon dapat berikatan dengan lebih kuat terhadap estrogen reseptor. Equol (7-hydroxy-3-(4-hydroxyphenyl)-

chroman) merupakan estrogen nonsteroid dari golongan isoflavon. Bentuk isoflavon ini secara eksklusif merupakan produk dari metabolisme bakterial intestin dari diet isoflavon dan menimbulkan aktivitas estrogenik, memiliki afinitas terhadap kedua estrogen reseptor. Equol memiliki pengaruh terhadap aktivitas antioksidan dibandingkan dengan yang lain. Ini merupakan produk akhir dari biotransformasi dari fitoestrogen daidzein. Sekali terbentuk, equol menjadi bersifat relatif stabil.

Setelah ingesti, isoflavone dihidrolisis oleh glikosidase intestin, melepaskan aglikon, daidzein, genistein, dan glisitein. Mereka kemudian diarbsorbsi atau dimetabolisme lebih lanjut menjadi beberapa metabolit spesifik, termasuk equol dan p-ethylphenol. Perpanjangan dari metabolisme ini sangat bervariasi tergantung individunya dan dipengaruhi oleh komponen dietnya. Kandungan karbohidrat tinggi, yang menyebabkan peningkatan fermentasi intestinal, menghasilkan biotranformasi fitoestrogen menjadi lebih panjang sehingga menyebabkan peningkatan pembentukan equol.

Paruh waktu daidzein dan genistein diukur dari kurva muncul dan hilangnya mereka dalam plasma menunjukkan konsentrasi puncak pada 6-8 jam setelah pemberian genistein atau daidzein senyawa murni. Farmakokinetik dari isoflavon sangat penting untuk membuat rekomendasi yang mengacu pada efikasi jangka panjang dalam studi klinis.

\section{KESIMPULAN DAN SARAN}

Hasil penelitian ini dapat disimpulkan bahwa konsumsi susu kedelai secara rutin dapat menurunkan insiden hipertensi. Untuk mendapatkan gambaran yang lebih jelas tentang mekanisme kerja susu kedelai dalam proses proteksi terhadap resiko penyakit kardiovaskuler, maka dapat dilakukan penelitian lebih lanjut dengan pendekatan biologi molekuler

\section{DAFTAR PUSTAKA}

Anderson, T.J. 1999. Assessment and Treatment of Endothelial Dysfunction in Humans. J. Am. Coll. Cardiol. 34 : 631-638.

Bonetti, P.O., Lerman, L.O., Lerman. A., 2003. Endothelial Dysfunction: A Marker of Atherosclerotic Risk. Arterioscler. Thromb. Vasc. Biol. 23:168-175.

Cai, H., dan D.G. Harrison. 2000. Endothelial Dysfunction in Cardiovaskular Diseases: The Role of Oxidant Stress. Circ. Res. 87:840-844.

Departemen Kesehatan Republik Indonesia. 2013. Riset Kesehatan Dasar. Departemen Kesehatan. Jakarta.

Giraldez, R.R., Panda, A., Zweier, J.L., 2000. Endothelial Dysfunction Does not Require Loss of Endothelial Nitric Oxide Synthase. Am. J. Physiol. Heart. Circ. Physiol. 278: H2020H2027.

Liu, H., Zang, C., Zeng, W., 2006. Estrogenic and Antioxidant effects of a 
Phytoestrogen Daidzein on Ovarian Germ Cells in Embryonic Chickens. Domest. Anim. Endocrinol. 31: 258268.

Mendelsohn, M.E. dan R.H. Karas. 1999. The Protective Effects of Estrogen on the Cardiovascular System. N. Eng. J. Med. 340(23): 1801-1811.

Price, S.A, dan L. Wilson. 2005. Patofisiologi: Konsep Klinis Proses Penyakit. Edisi 6. Jakarta: EGC.

Persky, A.M., Green, P.S., Stubley, L., Howell, C.O., Zaulyanov, L., Brazeau, G.A., Simpkins, J.W. 2000. Protective Effect of Estrogens against Oxidative Damage to Heart and Skeletal Muscle in Vivo and in Vitro. PSEBM. 223 : 59-66.

Setchell, K.D.R dan A. Cassidy. 1999. Dietary isoflavone: Biological effects and relevance to human health. J. Nutr. 129:758S-167S.

Shen, J., White, M., Husband, A.J., Hambly, B.D., Bao, S. 2006. Phytoestrogen derivatives differentially inhibit arterial neointimal proliferation in a mouse model. Eur. J. Pharmacol. 548:123-128.

Tham, D.M., Gardner, C.D., Haskell, W.L. 1998. Potential health benefits of dietary phytoestrogens: A review of the clinical, epidemiological, and mechanistic evidence. J. Clin. Endocrinol. Metab. 83:2223-2235.

Tamaya, T. 2005. Phytoestrogens and reproductive biology. Reprod Med Biol. 4: 225-229.

Yuniastuti. 2008. Efek Pemberian Genistein terhadap Jumlah dan Fungsi Endotel Aorta (Rattus norvegicus) Hipoestrogen. Tesis. Universitas
Brawijaya Program Pascasarjana Program Studi Magister Biomedik. Malang

Yuniastuti, T. dan A. Christiana. 2013. Pengaruh Diet Makanan Berbasis Kedelai dengan Keluhan Gangguan Menopause. Malang: STIKES Widyagama Husada. 
